\title{
Characterising burden of treatment in cystic fibrosis to identify priority areas for clinical trials
}

Gwyneth Davies ${ }^{1 *}$, Nicola J Rowbotham ${ }^{2 *}$, Sherie Smith ${ }^{2 *}$, Zoe C Elliot ${ }^{3}$, Katie Gathercole ${ }^{4,5}$, Oli Rayner $^{6}$, Paul A Leighton ${ }^{7}$, Sophie Herbert ${ }^{2}$, Alistair JA Duff ${ }^{8}$, Suja Chandran ${ }^{9}$, Tracey Daniels $^{10}$, Edward F Nash ${ }^{11}$, Alan R Smyth². *joint first authors.

\section{Institutions:}

1. Respiratory, Critical Care and Anaesthesia Section, UCL Great Ormond Street Institute of Child Health, London, UK

2. Evidence Based Child Health Group, University of Nottingham, Nottingham, UK

3. Parent of Children with CF, Nottingham, UK

4. University of Leeds, Leeds, UK

5. Person with $\mathrm{CF}$, Leeds, UK

6. Person with $\mathrm{CF}$, Plymouth, UK.

7. Centre of Evidence Based Dermatology, University of Nottingham, Nottingham, UK

8. Leeds Teaching Hospitals NHS Trust, Leeds, UK

9. Paediatric CF Service, Kings College Hospital NHS Foundation Trust, London, UK.

10. Department of Physiotherapy, York Hull Adult CF Unit, York Teaching Hospital NHS Foundation Trust, York, UK

11. West Midlands Adult CF Centre, University Hospitals Birmingham NHS Foundation Trust, Birmingham, UK

Corresponding author: Dr Gwyneth Davies. Email: gwyneth.davies@ucl.ac.uk

Word count: 1298 words. Abstract: 143 words

Keywords: Treatment burden, cystic fibrosis, clinical trial, co-production, priority setting 
Unstructured abstract: In a recent James Lind Alliance Priority Setting Partnership in cystic fibrosis (CF) the top priority clinical research question was: "What are effective ways of simplifying the treatment burden of people with CF?" We aimed to summarise the lived experience of treatment burden and suggest research themes aimed at reducing it. An online questionnaire was co-produced and responses subjected to quantitative and thematic analysis. 941 survey responses were received (641 from lay community). People with CF reported a median of 10 (interquartile range: 6-15) current treatments. Seven main themes relating to simplifying treatment burden were identified. Treatment burden is high, extending beyond time taken to perform routine daily treatments, with impact varying according to person-specific factors. Approaches to communication, support, evaluation of current treatments, service set-up, and treatment logistics (obtaining/administration) contribute to burden, offering scope for evaluation in clinical trials or service improvement. 


\section{Introduction:}

The James Lind Alliance Priority Setting Partnership (JLA PSP) in cystic fibrosis (CF) used a robust methodology to develop the top 10 clinical research questions, through discussions with the clinical and patient community (1). A number of the top 10 questions are complex and need to be explored further before they can be transformed into testable hypotheses for clinical study. An example is the first question: "What are effective ways of simplifying the treatment burden of people with CF". The recent US Cystic Fibrosis Foundation Insight CF survey ranked 'Making it easier to do daily treatments' in their top three research priority topics, confirming the relevance of this issue globally (2). The work described in this paper aimed to:

1) Summarise the lived experience of treatment burden in CF.

2) Suggest themes that can generate research questions for future clinical trials of approaches to reducing treatment burden.

Some of these results have been previously published as abstracts $(3,4)$ and shared on social media.

\section{Methods:}

The UK National Institute for Health Research (NIHR) supports the JLA and agreed to this work under the branding "James Lind CF2". The work was led by a steering group, representative of the UK CF community (both lay and professional) (1). An electronic questionnaire (SurveyMonkey ${ }^{\mathrm{TM}}$ ) was coproduced to understand the size and diversity of the treatment burden in people with CF (PWCF) and potential strategies to simplify it (Online Supplementary file 1). The survey was designed to be inclusive, with no minimum age or restrictions on location, and was open for four weeks between March and April 2018. It was promoted via Twitter ${ }^{\mathrm{TM}}$ (@questionCF), professional networks, UK CF Trust, and NIHR. Responses were subjected to quantitative analysis (closed questions) and thematic analysis (free text comments). Two reviewers independently reviewed all responses in order to generate topics that represented recurring themes into which the data was coded. Spearman rank correlations were used to identify associations between variables.

\section{Results:}

Of the 941 survey responses we received, 189 (20\%) came from PwCF, 452 (48\%) came from relatives or friends of PwCF, and 300 (32\%) came from health professionals. Survey participant characteristics are summarised in Table 1. Mean age of respondents was 41.5y (range 14y-84y); mean age of PwCF who were responding (or who were the subject of a response), was 15.6y (range $2 m-59 y)$. Responses came from 21 countries; with 87\% being from UK residents (390/445 where 
location was known). Not all survey participants responded to each question (Online Supplementary file 2, table E1).

PwCF or their carers reported a median of 10 (interquartile range, IQR, 6-15) current treatments, with $24 \%$ (71/292 respondents) receiving short-term oral medications and $10 \%$ (30/292) intravenous antibiotics at the time of participation. The median total daily time taken for treatments was 2 hours (IQR 2-3 hours). The total number of treatments was significantly associated with total daily time spent on treatments $(r=0.42, p=<0.001, n=269)$ - Online Supplementary file 2 . In total $70 \%(240 / 343)$ of PwCF miss out on treatments when busy or tired, most commonly, nebulised therapies and airway clearance techniques (ACT). When PwCF were asked if they found some treatments more difficult than others 60\% (200/333) agreed. Examples of difficult treatments mentioned frequently included nebulised therapy, airway clearance, and medication "admin" (i.e. the time, effort and psychological impact of requesting and obtaining medications and equipment). Difficulties in obtaining medication were reported by $76 \%$ (241/317) of PwCF and/or their relatives or friends. When PwCF were asked if they thought their treatment plan takes into account their personal situation, 58\% (184/318) felt it did and 22\% (71/318) felt it did not, with 63 respondents unsure. For those to whom questions relating to employment or education were considered applicable, $87 \%$ $(202 / 233)$ felt that their treatments get in the way of their job or career and $77 \%(168 / 217)$ in the way of their education. Two thirds $(67 \% ; 207 / 311)$ reported that their treatments get in the way of family relationships, relationship with a partner (69\%; 162/236), and relationships with friends (75\%; 227/304). An impact of treatments on socialising and on sports and hobbies was reported by $81 \%$ $(250 / 308)$ and $80 \%(231 / 289)$ respectively.

PwCF and professionals listed the same five CF treatments as being "most important" (Table 2a). There was also agreement between the top two most burdensome treatments (Table 2b): airway clearance techniques and long term nebulised antibiotics. Key themes relating to why lay and professional respondents selected ACTs as burdensome included: time taken, dislike, boredom, battles with children to do ACTs, and a lack of immediate evidence of effect. Similar responses were received for nebulised antibiotics, with the addition of concerns about side effects and cleaning nebulisers. Several healthcare professionals voiced concern that selecting the 'most important' treatment was impossible as it would be person-specific.

We asked health care professionals: "With the advent of CFTR modulators it may be possible to stop or reduce some existing treatments for those patients taking these drugs. Would you support a stopping trial if this was to be carried out?" with endorsement coming from $78 \%$ (129/165). This question was not present in the lay questionnaire. 
Seven main themes relating to simplifying treatment burden were identified through the survey (table 3).

\section{Discussion:}

Our survey confirms that the lived experience of treatment burden in CF is high, and extends beyond time taken to perform routine daily treatments, with an impact on daily life which varies according to patient and family factors. We have shown concordance between lay and professional perceptions of both important and burdensome treatments in CF. In the treatments considered most burdensome (airway clearance and nebulised antibiotics), time burden featured particularly highly. These 'top two' burdensome treatments were also most likely to be missed, supporting the findings of Sawicki et al(5) in a larger sample size. Our results for time spent on treatment, and number of treatments, are consistent with previously published surveys of treatment burden in CF (6-8). Although not explicitly explored in our survey, recent evidence suggests that social support may reduce perceived treatment burden(9).

Treatment complexity in CF increases with age(10). The demographics of PwCF are changing, with growing numbers in adult clinics (11), and more living with established disease and its associated treatment burden. The current landscape for treatment is likely to undergo rapid change over the next five years, reflecting drugs targeting the underlying molecular defect. Our results show support amongst CF health care professionals for 'stopping trials' of existing treatments for patients on CFTR modulators. Although beyond the scope of this survey, further exploration of this topic (including safety, necessity and objective of any trial) within the lay and professional community will be important. Other opportunities to simplify treatment could be explored in clinical studies, such as potential interventions to engage patients in shared decision-making and goal setting.

Our study had several limitations. It is possible that some survey responses were biased by the wording of questions, particularly those with an introductory statement. For some questions it was felt that this information was necessary to show understanding in order to encourage honest and open responses. Survey questions went through a rigorous review by both lay and professional members of the steering group prior to inclusion. A further limitation is the variable number of respondents answering each survey question. This may have reflected questionnaire design and length, and we have considered this for subsequent surveys exploring other James Lind Alliance CF research priorities.

\section{Conclusions:}

Treatment burden in CF is substantial and multifactorial. We have shown that approaches to communication, support, evaluation of current treatments, service set-up, and treatment logistics 
(obtaining or administering treatments) contribute to burden and offer scope for evaluation in clinical trials or service improvement. There is support amongst professionals for a trial of stopping or reducing some existing treatments for those on CFTR modulators.

Acknowledgements: Members of the James Lind Alliance CF2 steering group include: Brownlee K, Collins S, Daniels T, Davies G, Duff AJA, Elliot ZC, Gathercole K, Hurley MN, Leighton PA, Rayner O, Rowbotham NJ, Smith S, Chandran S, Nash EF, Smyth AR (Chair), Wilson P. We would like to thank PwCF and their families, and the multi-disciplinary professional CF community for taking part in this survey. This work was funded by the UK CF Trust, and the University of Nottingham. G Davies was supported an NIHR Academic Clinical Lectureship at UCL. N Rowbotham is an NIHR Academic Clinical Fellow at University of Nottingham.

Conflict of Interest statement: A Duff reports personal fees and non-financial support from Chiesi pharmaceuticals, personal fees from Novartis pharmaceuticals, outside the submitted work. A Smyth reports grants from Vertex, personal fees from Vertex and support for educational meetings from Teva, outside the submitted work; In addition, A Smyth has a patent 'Alkyl quinolones as biomarkers of Pseudomonas aeruginosa infection and uses thereof' issued. N Rowbotham reports non-financial support from Teva, outside the submitted work. T Daniels reports personal fees from Profile pharma, personal fees from Gilead, personal fees from Chiesi, other from Teva, personal fees from Vertex, outside the submitted work. All other authors have no other conflict of interest to declare.

\section{References}

1. Rowbotham NJ, Smith S, Leighton PA, Rayner OC, Gathercole K, Elliott ZC, et al. The top 10 research priorities in cystic fibrosis developed by a partnership between people with CF and healthcare providers. Thorax. 2018;73(4):388-90.

2. Hollin IL, Donaldson SH, Roman C, Aliaj E, Riva D, Boyle M, et al. Beyond the expected: Identifying broad research priorities of researchers and the cystic fibrosis community. Journal of cystic fibrosis : official journal of the European Cystic Fibrosis Society. 2019;18(3):375-7.

3. Rowbotham NJ, Smith SJ, Elliott ZC, Duff A, Rayner O, Davies G, et al. Understanding the Treatment Burden in Cystic Fibrosis: A Step Towards a Trial of Stopping Treatment? (abstract). Pediatric pulmonology. 2018;53(S2).

4. Davies G, Rowbotham NJ, Smith S, Leighton P, Elliot ZC, Gathercole K, et al. Assessment of treatment burden and approaches to simplifying burden of treatment in cystic fibrosis: a mixed methods study (abstract). Journal of Cystic Fibrosis. 2019;18 (Suppl 1):S187. 
5. Sawicki GS, Heller KS, Demars N, Robinson WM. Motivating adherence among adolescents with cystic fibrosis: youth and parent perspectives. Pediatric pulmonology. 2015;50(2):127-36.

6. Sawicki GS, Sellers DE, Robinson WM. High treatment burden in adults with cystic fibrosis: challenges to disease self-management. Journal of cystic fibrosis : official journal of the European Cystic Fibrosis Society. 2009;8(2):91-6.

7. Cystic Fibrosis Insight Survey- Report on the 2017 and 2018 Surveys. UK Cystic Fibrosis Trust; 2018.

8. Quittner AL, Zhang J, Marynchenko M, Chopra PA, Signorovitch J, Yushkina Y, et al. Pulmonary medication adherence and health-care use in cystic fibrosis. Chest. 2014;146(1):142-51. 9. Flewelling KD, Sellers DE, Sawicki GS, Robinson WM, Dill EJ. Social support is associated with fewer reported symptoms and decreased treatment burden in adults with cystic fibrosis. Journal of cystic fibrosis : official journal of the European Cystic Fibrosis Society. 2019;18(4):572-6.

10. Sawicki GS, Ren CL, Konstan MW, Millar SJ, Pasta DJ, Quittner AL, et al. Treatment complexity in cystic fibrosis: trends over time and associations with site-specific outcomes. Journal of cystic fibrosis : official journal of the European Cystic Fibrosis Society. 2013;12(5):461-7.

11. UK CF Registry Annual Report 2017. Published Aug 2018. Available at https://www.cysticfibrosis.org.uk/the-work-we-do/uk-cf-registry/reporting-and-resources. 
Tables

Table 1. Survey participant characteristics

\begin{tabular}{|c|c|c|}
\hline & $\mathbf{N}$ & $\%$ \\
\hline Total survey participants* & 941 & - \\
\hline \multicolumn{3}{|l|}{ Lay and professional representation } \\
\hline Person with CF & 189 & 20 \\
\hline A parent of a child or children with CF & 349 & 37 \\
\hline Spouse or partner of a person with CF & 8 & 1 \\
\hline Other relative or friend of a person with CF & 95 & 10 \\
\hline Total lay participants & 641 & 68 \\
\hline $\begin{array}{l}\text { A health care professional or researcher working } \\
\text { with CF }\end{array}$ & 300 & 32 \\
\hline Healthcare professional occupation known & 289 & - \\
\hline Physiotherapist & 64 & 22 \\
\hline Dietitian & 55 & 19 \\
\hline Respiratory Paediatrician & 37 & 13 \\
\hline Respiratory Physician & 20 & 7 \\
\hline Nurse & 33 & 11 \\
\hline Psychologist & 24 & 8 \\
\hline Researcher & 22 & 8 \\
\hline Pharmacist & 14 & 5 \\
\hline Social worker & 11 & 4 \\
\hline Junior Doctor & 7 & 2 \\
\hline General Practitioner & 2 & 1 \\
\hline \multicolumn{3}{|l|}{ Geographical location } \\
\hline Participant location known & 445 & - \\
\hline UK & 389 & 87 \\
\hline Europe (non UK) & 14 & 3 \\
\hline North America & 32 & 7 \\
\hline South America & 2 & $<1$ \\
\hline Asia & 2 & $<1$ \\
\hline Australia and New Zealand & 5 & 1 \\
\hline Non-UK unwilling to disclose & 1 & $<1$ \\
\hline \multicolumn{3}{|l|}{ Age of survey participants } \\
\hline Mean age (all participants), years (range) & \multicolumn{2}{|c|}{$41.5(14-84)$} \\
\hline $\begin{array}{l}\text { Mean age of PwCF who were responding (or who } \\
\text { were the subject of a response), years (range) }\end{array}$ & \multicolumn{2}{|c|}{$15.6(2-59)$} \\
\hline
\end{tabular}

Legend for table $1 .{ }^{*}$ Total number of participants answering at least one survey question. 
Table 2. Top 5 most important and burdensome treatments

a) Important

\begin{tabular}{|l|l|l|l|l|}
\hline Rank & Lay & $\mathrm{n}(\%)$ & Professional & $\mathrm{n}(\%)$ \\
\hline 1 & Pancreatic enzymes & $107(37)$ & Pancreatic enzymes & $58(35)$ \\
\hline 2 & Airway clearance & $34(12)$ & Airway clearance & $29(18)$ \\
\hline 3 & CFTR modulators & $27(9)$ & CFTR modulators & $19(12)$ \\
\hline 4 & Exercise and physical activity & $27(9)$ & Long term nebulised antibiotics & $19(12)$ \\
\hline 5 & Long term nebulised antibiotics & $24(8)$ & Exercise and physical activity & $16(10)$ \\
\hline
\end{tabular}

b) Burdensome

\begin{tabular}{|l|l|l|l|l|}
\hline Rank & Lay & $\mathrm{n}(\%)$ & Professional & $\mathrm{n}(\%)$ \\
\hline 1 & Airway clearance techniques & $68(24)$ & Airway clearance techniques & $66(42)$ \\
\hline 2 & Long term nebulised antibiotics & $53(19)$ & Long term nebulised antibiotics & $43(27)$ \\
\hline 3 & Pancreatic enzymes & $37(13)$ & $\begin{array}{l}\text { Regular intravenous ('IV') } \\
\text { antibiotics }\end{array}$ & $10(6)$ \\
\hline 4 & Regular intravenous ('IV') antibiotics & $22(8)$ & Exercise and physical activity & $6(4)$ \\
\hline 5 & Long term antibiotics by mouth & $15(5)$ & Insulin & $6(4)$ \\
\hline
\end{tabular}

Legend for table 2: a) Top 5 most important treatments according to lay and professional survey participants and b) Top 5 treatments to stop in an ideal world without consequence (Lay) or considered most burdensome (Professional). 
Table 3: Main survey themes from qualitative and quantitative analysis

\begin{tabular}{|c|c|c|}
\hline Topic & Example free-text survey response & Topic formulations \\
\hline \multirow[t]{3}{*}{$\begin{array}{l}\text { Individualised / } \\
\text { personalised care }\end{array}$} & \multirow[t]{3}{*}{$\begin{array}{l}\text { "I don't think I have ever even been } \\
\text { asked about my life plans by team! In } \\
\text { terms of work commitment they get } \\
\text { annoyed with me if I even try to } \\
\text { consider work, they honestly give the } \\
\text { impression it should all be about my } \\
\text { CF" (pwCF, age 30-35yrs, UK)) }\end{array}$} & $\begin{array}{l}\text { i) Lifestyle/work/familial } \\
\text { responsibilities can be } \\
\text { challenging and need to be } \\
\text { accommodated in } \\
\text { treatment plans. }\end{array}$ \\
\hline & & $\begin{array}{l}\text { ii) Personalised care plans to take } \\
\text { account of life and } \\
\text { disease progression } \\
\text { stages/patient's ability to cope } \\
\text { (psycho-socially). }\end{array}$ \\
\hline & & $\begin{array}{l}\text { iii) Advances in treatment move } \\
\text { towards greater tailored care. }\end{array}$ \\
\hline \multirow{3}{*}{$\begin{array}{l}\text { Psychological } \\
\text { aspects of } \\
\text { treatment burden }\end{array}$} & \multirow{3}{*}{$\begin{array}{l}\text { "It's everything overall. If it's feeling } \\
\text { difficult and I'm not seeing treatments } \\
\text { make a difference it's quite hard to feel } \\
\text { motivated to do any of it." (pwCF, age } \\
25-30, \text { UK) }\end{array}$} & $\begin{array}{l}\text { i) Interventions to support } \\
\text { psychological resilience. }\end{array}$ \\
\hline & & $\begin{array}{l}\text { ii) A need for improved } \\
\text { communications. }\end{array}$ \\
\hline & & $\begin{array}{l}\text { iii) A recognition that psycho- } \\
\text { social needs vary regardless of } \\
\text { treatment variations. }\end{array}$ \\
\hline \multirow[t]{3}{*}{$\begin{array}{l}\text { Technology } \\
\text { /telehealth }\end{array}$} & \multirow[t]{3}{*}{$\begin{array}{l}\text { "Digital appointments (so less traveling } \\
\text { and missing stuff) and maybe some fun } \\
\text { during nebs and physio. (PwCF, aged } \\
\text { 15-20yrs, UK) }\end{array}$} & $\begin{array}{l}\text { i) Use of telehealth interventions } \\
\text { to simplify/reduce treatment } \\
\text { burden. }\end{array}$ \\
\hline & & ii) Use of home-based devices. \\
\hline & & $\begin{array}{l}\text { iii) Improved equipment to } \\
\text { simplify treatment. }\end{array}$ \\
\hline \multirow{2}{*}{$\begin{array}{l}\text { Compliance/battles } \\
\text { with children, } \\
\text { teenagers and } \\
\text { healthcare team }\end{array}$} & \multirow{2}{*}{$\begin{array}{l}\text { "Having to overcome the 'why do I } \\
\text { have to do this?' From my } 7 \text { year old } \\
\text { grandson. He then tries to do it half } \\
\text { heartedly and we have to nag a wee } \\
\text { bit. Hate having to do this". } \\
\text { (Grandparent of two children with CF } \\
\text { aged 5-10yrs, UK) }\end{array}$} & $\begin{array}{l}\text { i) Use of gaming/technology to } \\
\text { engage children during treatment. }\end{array}$ \\
\hline & & $\begin{array}{l}\text { ii) Effective parenting programmes } \\
\text { to support treatment. }\end{array}$ \\
\hline
\end{tabular}




\begin{tabular}{|c|c|c|}
\hline \multirow[t]{2}{*}{$\begin{array}{l}\text { Medication } \\
\text { ordering and } \\
\text { prescriptions }\end{array}$} & \multirow{2}{*}{$\begin{array}{l}\text { "The administrative burden of being } \\
\text { your own care coordinator when you } \\
\text { have CF is something that needs to be } \\
\text { acknowledged. It takes far too much } \\
\text { time to get GP, hospital, pharmacy, } \\
\text { [nutrition supplement supplier] and } \\
\text { [home healthcare provider] to talk to } \\
\text { each other and do their jobs. I've } \\
\text { recently ended up crying on the phone } \\
\text { to my GP receptionist on a Friday } \\
\text { afternoon when the pharmacy were } \\
\text { refusing to let me have any [enzymes] } \\
\text { (!). It's also hard to arrange deliveries if } \\
\text { you work as the feed and drug } \\
\text { companies don't do evenings or } \\
\text { weekends" (pwCF, 30-35yrs, UK). }\end{array}$} & $\begin{array}{l}\text { i) Changes to prescription } \\
\text { management systems to } \\
\text { reduce the difficulties PwCF have } \\
\text { getting their } \\
\text { prescribed medicines. }\end{array}$ \\
\hline & & $\begin{array}{l}\text { ii) Improved communication in } \\
\text { prescription management across } \\
\text { the multi-disciplinary team }\end{array}$ \\
\hline \multirow[t]{2}{*}{$\begin{array}{l}\text { Side effects of } \\
\text { treatments }\end{array}$} & \multirow{2}{*}{$\begin{array}{l}\text { "Generally nebulisers make me cough, } \\
\text { feel tight and sometimes nauseous } \\
\text { without making me feel better. Airway } \\
\text { clearance makes me feel tired, gives } \\
\text { me a headache and often makes me } \\
\text { feel sick but it is worth it in order to } \\
\text { clear enough mucus to be able to } \\
\text { breathe" (PwCF aged 40-45yrs, UK). }\end{array}$} & $\begin{array}{l}\text { i) Better strategies for managing } \\
\text { side-effects. }\end{array}$ \\
\hline & & $\begin{array}{l}\text { ii) Managing side effects in a way } \\
\text { that does not escalate the } \\
\text { complexity of treatment }\end{array}$ \\
\hline Stopping trials & $\begin{array}{l}\text { "And there MUST be research on how } \\
\text { to take things away. I hate when new } \\
\text { meds come out now [because] it just } \\
\text { means we have to do more stuff. We } \\
\text { need more things coupled together. } \\
\text { We need treatments prioritized for us." } \\
\text { (parent of a child with CF age 5-10yrs, } \\
\text { USA) }\end{array}$ & $\begin{array}{l}\text { i) Need for research on how to } \\
\text { take treatments away }\end{array}$ \\
\hline
\end{tabular}

